\title{
Possible role of cell surface insulin degrading enzyme in cultured human lymphocytes
}

\author{
S. Yaso, K. Yokono, J.Hari, K. Yonezawa, K. Shii and S. Baba \\ Second Department of Internal Medicine, Kobe University School of Medicine, Kobe, Japan
}

\begin{abstract}
Summary. The kinetic changes of insulin receptors and cell surface insulin degrading enzyme were examined in Bri-7 cultured human lymphocytes after preincubation with or without insulin. The concentration of cell surface insulin degrading enzyme was determined by immunoenzymatic labeling method using a polyclonal antiserum to insulin degrading enzyme. In Bri-7 cells preincubated with $10^{-10}$ to $10^{-5} \mathrm{~mol} / \mathrm{l}$ insulin for $18 \mathrm{~h}$, the surface insulin receptors and insulin degrading enzyme decreased progressively as a function of the concentration of insulin in the preincubation medium. The surface insulin receptors and insulin degrading enzyme of cells preincubated with $10^{-6} \mathrm{~mol} / 1$ insulin were decreased to 25 and $35 \%$ of the control respectively. In Bri-7 cells preincubated with $10^{-6} \mathrm{~mol} / \mathrm{l}$ insulin for $30 \mathrm{~min}$ to $18 \mathrm{~h}$, the loss of surface insulin degrading enzyme was slightly slower than that of the receptors; however, the curves were essentially parallel to each other. Thus, the treatment of Bri-7 cells with insulin caused down-regulation of insulin receptors in a dose- and
\end{abstract}

time-dependent manner. Cell surface insulin degrading enzyme also decreased simultaneously. A combination of several insulin degradation assays (trichloroacetic acid precipitation, gel filtration and receptor rebinding) demonstrated that cell surface bound insulin remained intact, and that the degradation in Bri-7 cells seemed to be a limiting proteolysis of insulin. Furthermore, by the receptor rebinding method insulin degrading activity in cells after preincubation with $10^{-6} \mathrm{~mol} / 1$ insulin $(19.6 \pm 4.6 \%)$ was decreased, although not significantly, as compared with cells after preincubation without insulin $(24.6 \pm 4.8 \%)$. These results suggest a possible hypothesis that cell surface insulin degrading enzyme may be internalized with the insulin-receptor complex, and that it may degrade insulin during the intracellular process.

Key words: Insulin degrading enzyme, insulin receptor, internalization, cultured human lymphocytes, down-regulation, immunoenzymatic labeling, cell surface protease.
It is well recognized that incubation of various cell types with insulin leads to a decrease in the number of cell surface insulin receptors, a process termed down-regulation [1]. This loss of cell surface receptors may be linked with hormone internalization, because after insulin binds to its receptors, insulin-receptor complexes are internalized by absorptive endocytosis [2, 3]. Following this, insulin seems to be degraded in the intracellular sites [4-6]. Although the degradation of insulin has been extensively studied, the sites and enzymes of intracellular degradation have still not been determined. However, recent evidence suggests the presence of peptide intermediates of insulin metabolism in isolated cells [7, 8]; therefore, insulin seems to be initially degraded by a specific enzyme to intermediate forms and broken down in lysosomes to low molecular weight products [8]. Among many enzymes with the ability to degrade insulin, insulin degrading enzyme (IDE) [9, 10], also called insulin protease (EC 3.4.22.11, insulinase) [11] has been implicated in this process, since it cleaves insulin in a limited number of places which are consistent with the peptide intermediates in isolated cells [12, 13]. This enzyme mainly exists in the cytosol fraction, but also exists on the surface of various cell types $[14,15]$. Therefore, one possible mechanism of intracellular insulin degradation is that cell surface IDE may be internalized with the insulin-receptor complex and may degrade insulin during the intracellular process.

In order to examine this hypothesis, in the present study we have assayed cell surface IDE in Bri-7 cultured human lymphocytes in which insulin receptors were down-regulated by insulin.

\section{Materials and methods}

${ }^{125} \mathrm{I}$-insulin $(150-250 \mu \mathrm{Ci} / \mu \mathrm{g})$ was purchased from Dinabott RI Laboratories (Tokyo, Japan), pork monocomponent insulin from Novo Research Institute (Copenhagen, Denmark), RPMI 1640 medium from 
Flow Laboratories (McLean, Va, USA), fetal calf serum from GIBCO (Grand Island, NY, USA), bovine serum albumin (BSA, fraction V) from Sigma (St. Louis, Mo, USA) and Dulbeccos' modified Eagle medium (DMEM) from Nisui Biological Company (Tokyo, Japan). Polyclonal antiserum to IDE was obtained by immunization of rabbits using purified porcine skeletal muscle IDE by ammonium sulfate precipitation, chromatography on Bio-Gel P-200 and DEAE-cellulose and finally rechromatography on Sephadex G-200 [16]. The antiserum recognized not only purified porcine muscle IDE but also partially purified IDE from rat muscle cytosol and plasma membrane fractions [16]. Furthermore, by means of antiserum, IDE was identified on the surface of IM-9 cultured human lymphocytes [14], rat hepatoma cells [14], primary cultures of rat hepatocytes [14] and isolated mouse pancreatic acini [15].

Cell culture: Bri-7 cells, diploid B lymphocytes derived from peripheral lymphocytes of healthy subject, were obtained from Flow Laboratories [17]. The cells were grown in continuous culture at $37{ }^{\circ} \mathrm{C}$ in RPMI 1640 medium containing $10 \%$ fetal calf serum, $2 \mathrm{mmol} / 1$ glutamine, $50 \mu \mathrm{U} / \mathrm{ml}$ penicillin, $50 \mu \mathrm{g} / \mathrm{ml}$ streptomycin and $25 \mathrm{mmol} / 1$ HEPES, and equilibrated with $7 \% \mathrm{CO}_{2}$ and $93 \%$ humidified air.

Preincubation of Bri-7 cells with insulin: The Bri-7 cells at a concentration of $5 \times 10^{5} / \mathrm{ml}$ were preincubated with or without $10^{-10}-10^{-5} \mathrm{~mol} / 1$ concentration of unlabeled insulin at $37^{\circ} \mathrm{C}$ for the indicated time in the $\mathrm{CO}_{2}$ incubator. Following this preincubation, the cells were washed by the Kosmakos' method for the removal of cell surface bound insulin. In order to obtain the most optimal condition for dissociation of bound insulin from the cell surface, we employed the washing buffer consisting of DMEM ( $\mathrm{pH} 6.0$ ) containing $0.2 \%$ $\mathrm{BSA}$ at $30^{\circ} \mathrm{C}$ [18]. The cells were spun down and resuspended in assay buffer. The cell surface insulin receptors and IDE were then determined in both the control and insulin-preincubated cells.

Insulin binding assay: ${ }^{125} \mathrm{I}$-insulin was purified by gel filtration on a column of Sephadex G-50 before each experiment. The radioactivity was $99-100 \%$ precipitable in $7.5 \%$ trichloroacetic acid (TCA). The control and insulin-preincubated cells $\left(2 \times 10^{5}\right)$ were incubated in a total volume of $1 \mathrm{ml}$ of DMEM containing $1 \%$ BSA (pH 7.8) with 0.1-0.2 ng of purified ${ }^{125} \mathrm{I}$-insulin in the presence or absence of $33 \mu \mathrm{g}$ of unlabeled insulin. Incubation was conducted in polystylene tubes $(1 \times 7 \mathrm{~cm})$ at $15^{\circ} \mathrm{C}$ for $2 \mathrm{~h}$. The cells were then washed three times with
$500 \mu \mathrm{l}$ of ice-cold DMEM containing $0.2 \% \mathrm{BSA}$, and the radioactivity with the cells was measured in a gamma counter (Aloka, Tokyo, Japan). Non-specific binding was defined as radioactivity associated with cells in the presence of excess unlabeled insulin. Specific binding was obtained by subtracting the non-specific from total binding.

Immunoenzymatic labeling of cell surface IDE: Firstly, in order to examine the presence of cell surface IDE on Bri-7 cells, the cells were adjusted to a density of $1 \times 10^{6} \mathrm{cells} / \mathrm{ml}$. Normal rabbit serum (NRS) or anti-IDE serum were diluted, added to $0.5 \mathrm{ml}$ of the cultured cells and incubated for $30 \mathrm{~min}$ at $24^{\circ} \mathrm{C}$. After this incubation, the cell suspension was centrifuged at $200 \times \mathrm{g}$ for $5 \mathrm{~min}$, and the cell pellets were washed twice with $1 \mathrm{ml}$ of $0.01 \mathrm{~mol} / 1$ phosphate-buffered saline (PBS, $\mathrm{pH} 7.4$ ) and resuspended in $0.5 \mathrm{ml}$ of peroxidase conjugated anti-rabbit IgG (Miles-Yeda Ltd., Rehovot, Israel) at a final dilution of 1:200 in $0.01 \mathrm{~mol} / 1 \mathrm{PBS}$ with $1 \% \mathrm{BSA}$. After $60 \mathrm{~min}$ at $24^{\circ} \mathrm{C}$, the cells were washed as described above. The cell pellets were resuspended in $0.5 \mathrm{ml}$ of $0.1 \mathrm{~mol} / 1$ potassium phosphate, $\mathrm{pH} 6.0$, containing $0.4 \mathrm{mmol} / 1 \quad 2,2^{\prime}$-azinobis (3-ethyl-benzothiazoline-6-sulfonic acid) and $1.3 \mathrm{mmol} / 1 \mathrm{H}_{2} \mathrm{O}_{2}$ and incubated for $10 \mathrm{~min}$ at $24^{\circ} \mathrm{C}$. The enzyme reaction was stopped by cooling at $4{ }^{\circ} \mathrm{C}$ and centrifuging the cells. One $\mathrm{ml}$ of $0.1 \mathrm{~mol} / \mathrm{I}$ citrate-phosphate buffer, $\mathrm{pH} 2.8$, was added to $0.5 \mathrm{ml}$ of the supernatant and then the absorbance was read at $414 \mathrm{~nm}$. The changes of cell surface IDE in the Bri-7 cells preincubated with various concentrations of insulin for various indicated times were examined simultaneously.

Insulin degradation assays: Insulin degradation was examined in Bri-7 cells after preincubation with or without insulin. Bri-7 cells $\left(5 \times 10^{5} / \mathrm{ml}\right)$ were preincubated with or without $10^{-10}, 10^{-8}$ and $10^{-6} \mathrm{~mol} / \mathrm{l}$ concentration of insulin at $37^{\circ} \mathrm{C}$ for $18 \mathrm{~h}$ and washed by the Kosmakos' method as described above. The cells were spun down, resuspended in DMEM containing 1\% BSA (pH 7.4) and incubated with $0.1 \mathrm{ng} / \mathrm{ml}$ of ${ }^{125} \mathrm{I}$-insulin at $37^{\circ} \mathrm{C}$ for $1 \mathrm{~h}$. Degradation of ${ }^{125} \mathrm{I}$-insulin in the supernatant was determined by centrifuging the cell suspension and the adding $0.5 \mathrm{ml}$ of supernatant to $0.5 \mathrm{ml}$ of $15 \%$ TCA at $4^{\circ} \mathrm{C}$. The radioactivities in the precipitate and supernatant obtained after centrifugation were then counted (TCA method). Alternatively, $0.5 \mathrm{ml}$ of supernatant were added to $0.5 \mathrm{ml}$ of DMEM containing $2 \times 10^{6}$ freshly prepared Bri-7 cells. After incubation at $15^{\circ} \mathrm{C}$ of $2 \mathrm{~h}$, the fraction of ${ }^{125} \mathrm{I}$-insulin bound to receptors was measured as previously described (Rebinding method) [15]. Furthermore, in order

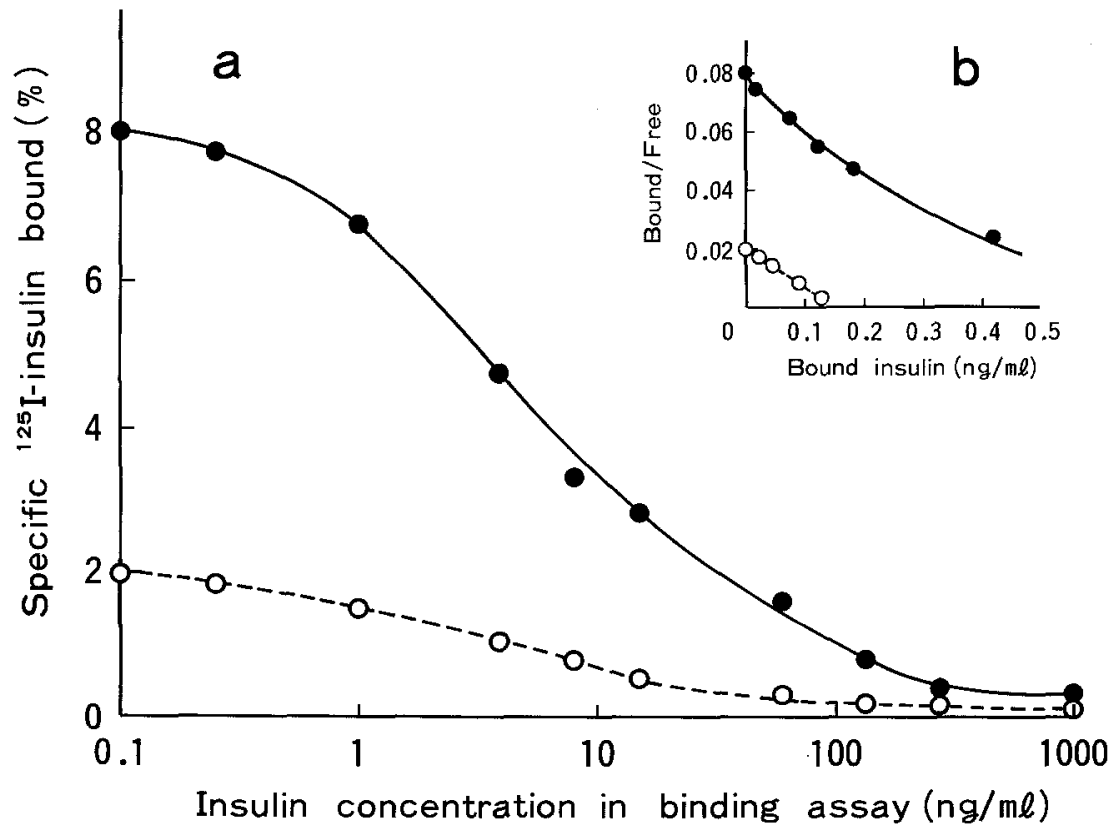

Insulin concentration in binding assay $(\mathrm{ng} / \mathrm{m} \ell)$
Fig. $1 \mathrm{a}$ and $b$. Effect of insulin exposure on cell surface insulin receptors in Bri-7 cells. a Bri-7 cells were preincubated with $(O)$ or without $\left(-10^{-6} \mathrm{~mol} / 1 \mathrm{insu}\right.$ lin for $18 \mathrm{~h}$ at $37^{\circ} \mathrm{C}$, washed by Kosmakos' method and then incubated with ${ }^{125} \mathrm{I}$-insulin and the indicated concentrations of unlabeled insulin for $2 \mathrm{~h}$ at $15^{\circ} \mathrm{C}$. Each point represents the mean of triplicate determinations. A representative experiment of the four experiments performed is shown. b Scatchard plots of the data are seen in Figure $1 \mathrm{a}$ 


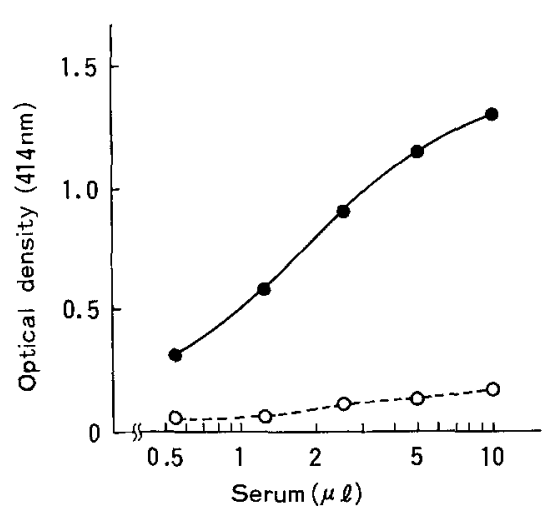

Fig. 2. Immunoenzymatic labelling of Bri-7 cells with anti-IDE serum. Bri-7 cells were incubated with the indicated amounts of either anti-insulin degrading enzyme (IDE) serum (-) or normal rabbit serum $(O)$ and then with a peroxidase-linked second antibody, and assayed spectrophotometrically. Each point represents the mean of triplicate determinations. A representative experiment of the three experiments performed is shown

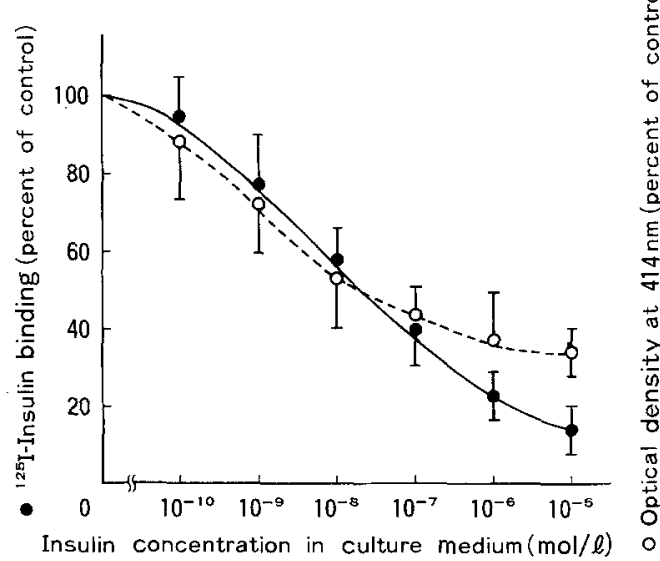

Fig. 3. Effect of down-regulation of the insulin receptor on cell surface IDE. Bri-7 cells were incubated with the indicated concentrations of insulin for $18 \mathrm{~h}$. The concentrations of cell surface insulin receptors (O) and IDE (O) were determined by ${ }^{125} \mathrm{I}$-insulin binding assay and immunoenzymatic labeling method respectively. Results are expressed as mean $\pm \mathrm{SD}$ of three different experiments

to examine whether cell surface bound insulin was intact or degraded, ${ }^{125} \mathrm{I}$-insulin was removed from the cell surface by using an acid extraction technique [19]. According to this method, surface bound insulin was extracted in the medium and only intracellular insulin was associated with cells. Bri-7 cells $\left(2 \times 10^{6}\right)$ were incubated with ${ }^{125} \mathrm{I}$-insulin at $37^{\circ} \mathrm{C}$ for $1 \mathrm{~h}$, cells were separated by centrifugation and incubated with the barbitol sodium acetate buffer $(\mathrm{pH} 3.0)$ for $5 \mathrm{~min}$ at $4^{\circ} \mathrm{C}$. The nonextractable (intracellular) radioactivity was solubilized in $0.1 \%$ Triton X-100, $4 \mathrm{~mol} / 1$ urea and $1.5 \mathrm{~mol} / 1$ acetic acid. Each extractable (cell surface) and nonextractable radioactivity was chromatographed on a Sephadex G-50 column $(0.7 \times 40 \mathrm{~cm})$ that was pre-equibrated with $4 \mathrm{~mol} / \mathrm{l}$ urea and $1.5 \mathrm{~mol} / \mathrm{l}$ acetic acid.

Statistical analysis: Results are given as mean $\pm S D$, and statistical evaluation of the data was made by Student's paired t-test. A $p$ value of $<0.05$ was considered statistically significant.

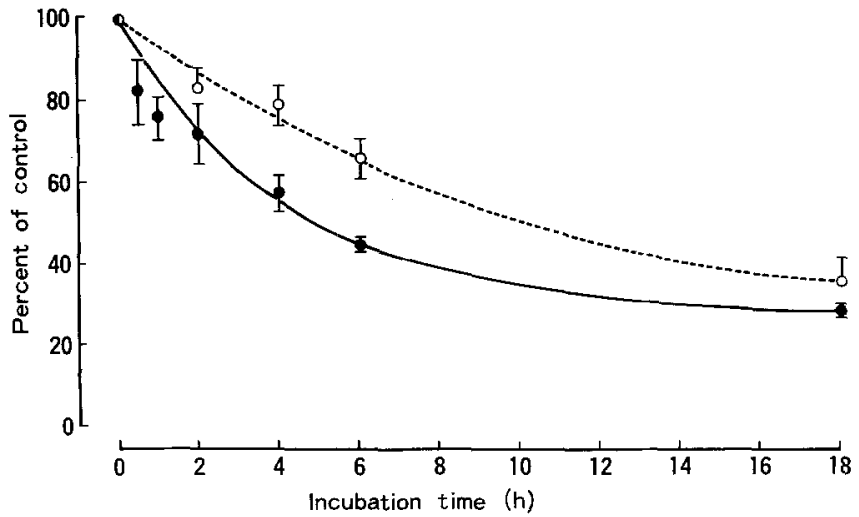

Fig.4. Time course of loss of cell surface insulin receptors and IDE during preincubation with $10^{-6} \mathrm{~mol} / 1$ insulin. Bri-7 cells were incubated with $10^{-6} \mathrm{~mol} / \mathrm{l}$ insulin for the indicated time. The concentrations of cell surface insulin receptors $(O)$ and IDE $(O)$ were determined by ${ }^{125} \mathrm{I}$-insulin binding assay and immunoenzymatic labelling method respectively. Results are expressed as mean $\pm \mathrm{SD}$ of three different experiments

\section{Results}

Bri-7 cells were preincubated with or without $10^{-6} \mathrm{~mol} / \mathrm{l}$ insulin for $18 \mathrm{~h}$ at $37^{\circ} \mathrm{C}$, washed with insulin free medium and then incubated with ${ }^{125}$ I-insulin and various concentrations of unlabelled insulin to measure surface insulin receptors (Fig. $1 \mathrm{a}$ ). At an insulin concentration ranging from 0.1 to $120 \mathrm{ng} / \mathrm{ml}$, Bri- 7 cells preincubated with insulin bound about $25 \%$ as much ${ }^{125} \mathrm{I}$-insulin as did the cells preincubated without insulin. Scatchard analysis indicated that the decrease in ${ }^{125} \mathrm{I}$-insulin binding to the cells which had been preincubated with insulin was the result of a decrease in the number of insulin receptors (Fig. 1b). Thus, insulin-induced receptor loss has been demonstrated in Bri-7 cells.

Either NRS or specific rabbit antiserum against IDE was incubated with Bri-7 cells. The binding of antibodies to the cells was quantified by the use of a second antibody that was coupled to peroxidase. Figure 2 shows that, with increasing quantities of anti-IDE serum, there was an increased amount of peroxidase activity bound to the cells. Bri-7 cells incubated with $1: 50$ dilution $(10 \mu \mathrm{l})$ of anti-IDE serum had 7 times more peroxidase activity than cells incubated with the same amount of NRS. Therefore, Bri-7 cells have not only plasma membrane insulin receptors, but also IDE, a plasma membrane protease.

Since the surface receptors in the Bri-7 cells were internalized along with the hormone and thus down-regulated by preincubation with insulin, surface IDE may be co-internalized with hormone-receptor complex. To determine the effect of chronic exposure to insulin on the level of surface IDE, Bri-7 cells were preincubated with various concentrations of unlabeled insulin $\left(10^{-10}\right.$ to $10^{-5} \mathrm{~mol} / \mathrm{l}$ ) for $18 \mathrm{~h}$, and cell surface receptors and IDE were measured (Fig. 3). Similar to the decrease of 
Table 1. ${ }^{125}$ I-insulin degradation in the supernatant from Bri-7 cells after preincubation with or without insulin

\begin{tabular}{lll}
\hline $\begin{array}{l}\text { Insulin concentration } \\
(\mathrm{mol} / \mathrm{l})\end{array}$ & \multicolumn{2}{l}{$\begin{array}{l}125 \mathrm{I} \text {-insulin degradation } \\
\left(\% / 1 \times 10^{6} \text { cells } / \mathrm{h}\right)\end{array}$} \\
\cline { 2 - 3 } & TCA method & Rebinding method \\
\hline 0 & $3.2 \pm 0.5$ & $24.6 \pm 4.8$ \\
$10^{-10}$ & $3.3 \pm 0.3$ & $23.5 \pm 5.3$ \\
$10^{-8}$ & $3.1 \pm 0.5$ & $23.8 \pm 4.7$ \\
$10^{-6}$ & $2.4 \pm 0.4$ & $19.6 \pm 4.6$ \\
\hline
\end{tabular}

Experiments were performed in triplicate. Data were expressed as mean \pm SD of three independent experiments. No significant difference was shown in cells after preincubation without versus with insulin.

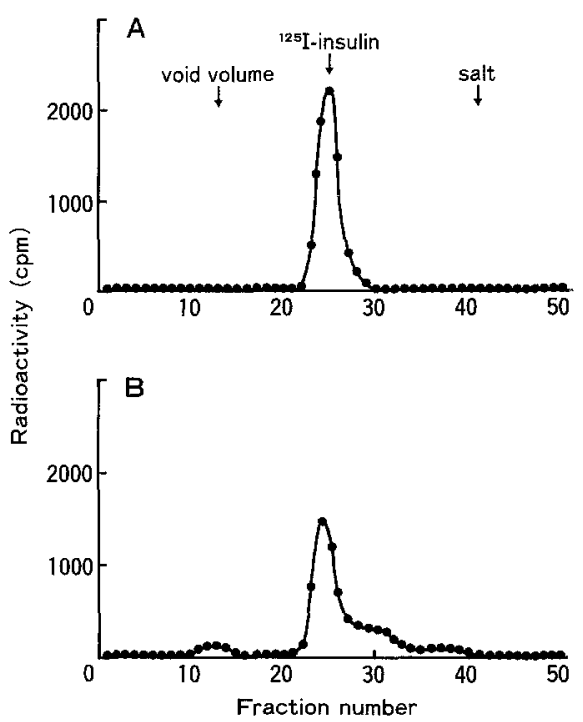

Fig.5. Determination of ${ }^{125} \mathrm{I}$-insulin degradation by gel filtration. Bri-7 cells were incubation with ${ }^{125} \mathrm{I}$-insulin at $37^{\circ} \mathrm{C}$ for $1 \mathrm{~h}$ and centrifuged. The cell-associated radioactivities were separated into cell surface (extractable) and intracellular (nonextractable) radioactivities by using an acid extraction technique. Nonextractable radioactivity was solubilized in $0.1 \%$ Triton $\mathrm{X}-100,4 \mathrm{~mol} / 1$ urea and $1.5 \mathrm{~mol} / 1$ acetic acid. Extractable (A) and nonextractable (B) radioactivities were applied to a Sephadex G-50 column. One experiment representative of three is shown

surface insulin receptors, the surface IDE decreased progressively as a function of the concentration of insulin in the preincubation medium. The surface insulin receptors and IDE of Bri-7 cells preincubated with $10^{-6} \mathrm{~mol} / \mathrm{1}$ insulin were decreased to 25 and $35 \%$ of the control respectively.

Figure 4 shows the effect of preincubation time on the loss of surface insulin receptors and IDE. Bri-7 cells were preincubated with $10^{-6} \mathrm{~mol} / 1$ insulin from $30 \mathrm{~min}$ to $18 \mathrm{~h}$, and cell surface receptors and IDE were measured. Fifty percent of the receptors were lost at $6 \mathrm{~h}$, and the level of the receptors achieved a steady state at $18 \mathrm{~h}$. Although the loss of surface IDE was slightly slower than that of receptors, the curves were essentially parallel to each other. Thus, the loss of cell surface receptors and IDE was directly related to the concentration of insulin and the preincubation time.

In order to examine the correlation between the amount of antibody binding to IDE and the enzymatic activity, insulin degradation in the supernatant was measured in Bri-7 cells after preincubation with or without insulin by TCA precipitation and receptor rebinding (Table 1). In the supernatants from both cells after preincubation with and without insulin, the apparent degradation of insulin was not detectable by the TCA method; however, fair amounts of insulin were degraded using by the rebinding method. As compared with cells after preincubation without insulin (24.6 \pm $4.8 \% / 1 \times 10^{6}$ cells $/ \mathrm{h}$ ), insulin degrading activity was fairly decreased, although not significantly, in cells after preincubation with $10^{-6} \mathrm{~mol} / 1$ insulin for $18 \mathrm{~h}(19.6 \pm$ $4.6 \% / 1 \times 10^{6}$ cells $/ \mathrm{h}$ ).

Finally, Figure 5 shows chromatographic patterns of extractable (cell surface) and nonextractable (intracellular) radioactivities from Bri-7 cells by an acid extraction. The extractable radioactivity was almost entirely eluted at the position of intact insulin, whereas the nonextractable radioactivity was eluted with the void volume, intact insulin and a small shift to right from insulin. No small fragments of ${ }^{125} \mathrm{I}$-insulin were found in the salt peak. Elution profiles of extractable and nonextractable radioactivities in Bri-7 cells preincubated with insulin were essentially similar to those in cells preincubated without insulin (data not shown). These results suggest that cell surface bound insulin has not been degraded and Bri-7 cells have degraded insulin to only a limited extent.

\section{Discussion}

Using a polyclonal antiserum to IDE, we evaluated cell surface IDE after exposing Bri-7 cultured human lymphocytes to insulin. The present studies demonstrate that Bri-7 cells contain not only insulin receptors but also IDE, a cell surface protease. The treatment of Bri-7 cells with insulin caused the down-regulation of insulin receptors in a dose- and time-dependent manner, with a simultaneous decrease in cell surface IDE.

Numerous studies on insulin degradation have been reported using isolated and cultured cells. The initial step in degradation of insulin by the target cell is binding of the hormone to receptors on the cell surface. Subsequent steps in the metabolism of insulin have been debated. Lysosomes may be implicated in the intracellular degradation of insulin. However, current studies have demonstrated that chloroquine, a lysosomal inhibitor, has little effect on ${ }^{125} \mathrm{I}$-insulin degradation in various tissues $[4,15,20,21]$, suggesting that lysosomes may have only a small role in the process of insulin degradation. On the contrary, IDE accounts for most of the insulin-degrading activity of various cell extracts $[9,12$, 15]. In addition, it has been shown that inhibitors which 
inhibit the activity of this enzyme also inhibit insulin degradation in the intact cell $[4,12,15,22]$. These reports are therefore consistent in indicating a role for IDE in insulin degradation.

On the other hand, direct morphological studies using fluorescent derivatives of insulin and microautoradiographic analysis have indicated that insulin is initially localized on plasma membranes and then internalized with its receptors via endocytosis [23, 24]. During the intracellular process, insulin appears to exist in unique vesicles called receptosomes [24] or compartments for uncoupling of receptor ligand complexes [25] which may eventually fuse with lysosomes. IDE on the cell surface may degrade insulin through three possible mechanisms. First, IDE may degrade insulin while the enzyme is present on the plasma membrane. Second, IDE may be shed into the incubation medium where the enzyme then acts to degrade insulin extracellularly. Third, IDE may be internalized with both insulin and its receptors, and then the enzyme may degrade insulin in an intracellular compartment. However, the first possibility does not appear to apply in this case because insulin bound to the surface of Bri-7 cells was still intact by judging from the acid wash technique. Furthermore, in contrast to prior studies demonstrating that IM-9 cells release in insulin degrading enzyme into their media [26], IDE from Bri-7 cells measured by immunoenzymatic labeling was not observed in the media after the exposure to insulin (unpublished observation). The second possibility, therefore, also could not be considered as the mechanism of insulin degradation in Bri-7 cells. Our present data support the third hypothesis that cell surface IDE may be internalized with the insulin receptor complex, and may degrade insulin during the process between dissociating insulin from its receptors and fusing the vesicle with lysosomes.

However, there is a considerable discrepancy between the amount of antibody binding to cell surface IDE and the insulin degrading activity in Bri-7 cells. The reason why the insulin degrading activity was not significantly decreased in down-regulated cells is currently unknown. One possible explanation for this discrepancy is that internalized insulin may be degraded by not only cell surface IDE but also IDE in the cytoplasm. Recently, Shii and Roth [27] produced four monoclonal antibodies to IDE from human erythrocytes. These antibodies, when microinjected into the cytoplasma of human hepatoma cells, have been shown to partly inhibit insulin degradation in the intact cell. These results suggest that a cytosolic IDE may account for a considerable part of the insulin degrading activity in the intact cell. The $\mathrm{pH}$ optimum for this enzyme was found to be 7.0, but the enzyme still shows its activity around pH 6.0 [28]. It is conceivable, therefore, that IDE degrades insulin in the cytoplasma at the optimum condition and IDE may also be active at the $\mathrm{pH}$ of endosomes. Thus, it is likely that both cell surface and cytosolic IDE, acting either individually or in concert, constitute a physiological mechanism by which the cellular response to insulin is terminated. Monoclonal antibodies against IDE will be very useful for studying the mechanism of intracellular degradation of insulin by cell surface and/or cytosolic IDE.

Acknowledgement. This work was supported in part by Grants-in-Aid for Scientific Research 58440083 and 58480426 from the Ministry of Education, Science and Culture, Japan.

\section{References}

1. Gavin JR, Roth J, Neville DM, De Meyts P, Buell DN (1974) Insulin-dependent regulation of insulin receptor concentration: a direct demonstration in cell culture. Proc Natl Acad Sci USA 71: 84-88

2. Baldwin DJ, Terris S, Steiner DF (1980) Regulation of insulin receptors. Evidence for involvement of an endocytotic internalization pathway. J Biol Chem 77: 5975-5978

3. Green A, Olefsky JM (1982) Evidence for insulin-induced internalization and degradation of insulin receptors in rat adipocytes. Proc Natl Acad Sci USA 79: 427-431

4. Duckworth WC, Runyan KR, Halban PA, Solomon SS (1981) Insulin degradation by hepatocytes in primary culture. Endocrinology $108: 1142-1147$

5. Olefsky JM, Saekow M (1982) Mechanism of insulin degradation by isolated rat adipocytes. Mol Cell Biochem 47:23-28

6. Misbin RI, Almira EC, Buynitzky SJ (1983) Insulin metabolism in rat hepatocytes. J Biol Chem 258: 2157-2162

7. Assoian RK, Tager HS (1982) Peptide intermediates in the cellular metabolism of insulin. J Biol Chem 257: 9078-9785

8. Misbin RI, Almira EC (1984) The fate of insulin in rat hepatocytes. Evidence for the release of an immunologically active frag ment. Diabetes 33: 355-361

9. Yokono K, Imamura Y, Shii K, Sakai H, Baba S (1981) Purification and characterization of insulin-degrading enzyme from pig skeletal muscle. Endocrinology 108: 1527-1532

10. Shii K, Baba S, Yokono K, Roth RA (1985) Covalent linkage of ${ }^{125} \mathrm{I}$-insulin to a cytosolic insulin-degrading enzyme. J Biol Chem 260: $6503-6506$

11. Duckworth WC, Stentz FB, Heinemann M, Kitabchi AE (1979) Initial site of insulin cleavage by insulin-protease. Proc Natl Acad Sci USA 76: 635-639

12. Stentz FB, Harris HL, Kitabchi AE (1985) Characterization insulin-degrading activity of intact and subcellular components of human fibroblasts. Endocrinology 116: 926-934

13. Yonezawa K, Yokono K, Yaso S, Hari J, Amano K, Kawase Y, Sakamoto T, Shii K, Imamura Y, Baba S (1986) Degradation of insulin-degrading enzyme and biological characteristics of its fragments. Endocrinology 118: 1989-1996

14. Yokono K, Roth RA, Baba S (1982) Identification of insulin-degrading enzyme on the surface of cultured human lymphocytes, rat hepatoma cells, and primary cultures of rat hepatocytes. Endocrinology 114: 1102-1108

15. Goldfine I, Williams J, Bailey A, Wong KY, Iwamoto Y, Yokono $\mathrm{K}$, Baba S, Roth R (1984) Degradation of insulin by isolated mouse pancreatic acini. Evidence for cell surface protease activity. Diabetes 33: 64-72

16. Yokono K, Imamura Y, Shii K, Mizuno N, Sakai H, Baba S (1980) Immunochemical studies on the insulin-degrading enzyme from pig and rat skeletal muscle. Diabetes 29:856-859

17. Thomas DB, Phillips B (1973) Evidence for membrane antigens specific for human B lymphoblasts. Clin Exp Immunol 14: 91-96

18. Kosmakos FC, Roth J (1980) Insulin-induced loss of the insulin receptor in IM-9 lymophocytes. J Biol Chem 255: 9860-9869

19. Haigler HT, Maxfield FR, Willingham MC, Pastan I (1980) Dansylcadaverine inhibits internalization of ${ }^{125}$ I-epidermal growth factor in BALB 3T3 cells. J Biol Chem 255: 1239-1241 
20. Marshall S, Olefsky JM (1979) Effects of lysosomotropic agents on insulin interactions with adipocytes. J Biol Chem 254: 10153-10160

21. Ward WF, Moss AL (1985) Effects of lysosomal inhibitors on ${ }^{125} \mathrm{I}$ insulin and ${ }^{125} \mathrm{I}$-asialofetuin degradation by the isolated perfused rat liver and isolated rat hepatocytes. Diabetes 34: 446-451

22. Goldstein B, Livingston J (1981) An evaluation of the importance of lysosomal and neutral cytosol proteases in insulin degradation by adipocytes. Endocrinology 108: 953-961

23. Carpentier JL, Gorden P, Freychet P, Le Cam A, Orci L (1979) Lysosomal association of internalized ${ }^{125}$ I-insulin in isolated rat hepatocytes: direct demonstration by quantitative electron microscopic autoradiography. J Clin Invest 63: 1249-1261

24. Willingham MC, Pastan I (1980) The receptosome: An intermediate organelle of receptor-mediated endocytosis in cultured fibroblasts. Cell 21: 67-77

25. Dautry-Varsat A, Lodish H (1984) How receptors bring proteins and particles into cell. Scientific American 250: 48-54
26. Misbin RI, Mehl TD (1980) Insulin receptor binding and degradation in IM-9 cultured human lymphocytes. Importance of extracellular degradation. J Endocrinol Invest 3:77 81

27. Shii K, Roth RA (1986) Inhibition of insulin degradation by hepatoma cells after microinjection of monoclonal antibodies to a specific cytosolic protease. Proc Natl Acad Sci USA 83: 4147-4151

28. Shii K, Yokono K, Baba S, Roth RA (1986) Purification and characterization of insulin-degrading enzyme from human erythrocytes. Diabetes 36: 675-683

Received: 16 June 1986

and in revised form: 24 November 1986

Dr. Koichi Yokono

Second Department of Internal Medicine

Kobe University School of Medicine

Kobe 650

Japan 